\title{
veterinary Observations on the helminths of harbour porpoises ( Phocoena phocoena) and common guillemots ( Uria aalge) from the Belgian and German coasts
}

L. Brosens, T. Jauniaux, U. Siebert, et al.

Veterinary Record 1996 139: 254-257

doi: 10.1136/vr.139.11.254

Updated information and services can be found at:

http://veterinaryrecord.bmj.com/content/139/11/254

These include:

Email alerting Receive free email alerts when new articles cite this article. Sign up in the service box at the top right corner of the online article.

Notes

To request permissions go to:

http://group.bmj.com/group/rights-licensing/permissions

To order reprints go to:

http://journals.bmj.com/cgi/reprintform

To subscribe to BMJ go to:

http://journals.bmj.com/cgi/ep 
The liver is of major importance in certain haemorrhagic diseases because most coagulation factors are synthesised there (Oldstone and others 1982). The hepatic lesions, including the destruction of hepatocytes, reported in this study after seven and 12 days, correspond with the histological (Sierra and others 1991), immunohistological (Fernández and others 1992a, Pérez and others 1994) and ultrastructural (Sierra and others 1991) findings of acute African swine fever. Although such lesions may account for the decreased synthesis of coagulation factors during the most critical phases of the disease, physiopathological results indicate that the destruction of hepatocytes, although certainly involved, does not determine the final outcome of this haemorrhagic disease (Villeda and others 1993).

The results of this study suggest that African swine fever virus isolate E75 acts directly and indirectly on various cell types actively involved in haemostasis. Morphopathologically, the mechanisms related to haemorrhage after the infection consisted of the activation and extensive destruction of monocytes/ macrophages, disseminated intravascular coagulation, and infection and necrosis of megakaryocytes. These findings resemble the pathogenesis of haemorrhagic fever in human beings by other viruses which act through direct effects on cell function and/or through the activation of immune and inflammatory pathways (Halstead and O'Rourke 1977, Cosgriff 1989).

Acknowledgements. - The authors thank Dr F. Gonzalvo and Dr J. Dominguez, at the Institut Nacional de Investigaciones Agrarias de Madrid, for determining the African swine fever antibody titres.

\section{References}

ANDERSON. E. C.. WILLIAMS, S. M., FISHER-HOCH, S. P. \& WILKINSON, P. J. (1987) Research in Veterinary Science 42, 387

BROWN. F. (1986) Intervirology 25, 141

CARRASCO, L.. FERNÁNDEZ. A.. GÓMEZ-VILLANDOS. J. C.. MOZOS. E.. MENDEZ. A. \& JOVER. A. (1992) Histology and Histopathology 7, 421

COLGROVE. G. S., HAELTERMAN. E. D. \& COGGINS. L. (1969) American Journal of Veterinary Research 30, 1343

COSGRIFF, T. M. (1989) Review of Infectious Diseases 11, 672

DARDIRI, A. H. \& HESS, W. R. (1970) Proceedings of the 74th annual meeting of the US Animal Health Association. p 213

EDWARDS, J. F., DODDS, J. W. \& SLAUSON, D. O. (1985) Veterinary Pathology 22, 171

FERNÁNDEZ, A.. PÉREZ. J.. CARRASCO. L.. SIERRA. M. A.. SÁNCHEZVIZCAÍNO. J. M. \& JOVER. A. (1992a) American Journal of Veterinary Research 53, 1462

FERNÁNDEZ, A.. PÉREZ, J.. MARTíN DE LAS MULAS, J., LIBRADO. L.. DOMÍNGUEZ, J. \& SIERRA, M. A. (1992b) Journal of Comparative Pathology. 107,81

HALSTEAD. S. B. \& O'ROURKE. E. J. (1977) Journal of Experimental Medicine 146,201

MEBUS. C. A. (1988) Adrances in Virus Research 35, 251

OLDSTONE. M. B. A.. SINHA. Y. N.. BOLUNT, P., TISHONE. A., RODRÍGUEZ. M.. WEBEL. R. \& LAMPERT. P. W. (1982) Science 218, 770

PAN. I. C. (1987) African Swine Fever. Ed Y. Becker. Boston. p 81

PÉREZ. J.. RODRÍGUEZ. F., FERNÁNDEZ. A.. MARTÍN DE LAS MULAS. J., GÓMEZ-VILLAMANDOS. J. C. \& SIERRA. M. A. (1994) Journal of Veterinary Diagnostic Investigations $\mathbf{6}, 360$

SÁNCHEZ-VIZCAÍNO, J. M., SLAUSON, D. O., RUIZ GONZALVO, F. \& VALERO. F. (1981) American Journal of Veterinary Research 42,1335

SANZ. A.. GARCÍA-BARRENO, B., NOGAL. M. L.. VIÑUELA. E. \& ENJUANES. L. (1985) Journal of Virology 34, 199

SIERRA. M. A.. GÓMEZ-VILLAMANDOS, J. C., CARRASCO. L.. FERNÁNDEZ, A. \& MOZOS, E. (1991) Veterinary Pathology 28, 178

SIERRA. M. A.. QUEZADA. M.. FERNÁNDEZ, A., CARRASCO, L., GÓMEZVILLAMANDOS. J. C.. MARTÍN DE LAS MULAS, J. \& SÁNCHEZVIZCAÍNO, J. M. (1989) Veterinary Pathology 26, 173

VILLEDA. C. J., WILLIAMS. S. M.. WILKINSON. P. J. \& VIÑUELA. E. (1993) Archives of Virology 130, 71

\title{
Observations on the helminths of harbour porpoises (Phocoena phocoena) and common guillemots (Uria aalge) from the Belgian and German coasts
}

\author{
L. Brosens, T. Jauniaux, U. Siebert, H. Benke, F. Coignoul
}

Veterinary Record (1996) 139, 254-257

Between February 1990 and July 1991,18 harbour porpoises
(Phocoena phocoena) and 248 common guillemots (Uria
aalge), found dead along the Belgian and German coasts, were
examined for their burden of helminths. A total of three
species were found in the guillemots (one cestode, one nema-
tode and one pentastomid), and six species in the porpoises
(one trematode, one cestode and four nematodes). Among the
guillemots the burden of helminths was not statistically differ-
ent between juvenile and adult birds. The deaths of the birds
were apparently not related to the parasite infections. In con-
trast, the adult porpoises were more heavily parasitised than
the juveniles, except for one young porpoise stranded on the
Belgian coast. In the porpoises, four species of parasites had a

L. Brosens, MS, Biol, T. Jauniaux, DVM, F. Coignoul, DVM, PhD, Department of Pathology, Faculty of Veterinary Medicine, University of Liège, Campus du Sart-Tilman, Bat. B43, B-4000, Liège, Belgium

U. Siebert, DVM, PhD Department of Pathology, College of Veterinary Medicine, University of Giessen, Germany

H. Benke, PhD, Research and Technology Centre of the West Coast, University of Kiel, Germany pathological effect and Torynurus convolutus was responsible for the death of one animal from the Belgian coast and three from the German coast.

IN the past few years, increased numbers of dead marine mammals and seabirds have been reported along the shores of the North Sea (Camphuysen 1989). Various causes have been suggested, including infectious agents, toxic chemicals, parasites, oil pollution, the gradual exhaustion of food supplies and accidental catches by fishermen (Kinze and others 1988). A better understanding of the physiology, ecology, ethology and pathology of these species is a prerequisite to understanding the complex phenomenon of their decline, and a multidisciplinary approach will be necessary.

In the context of studies carried out in Belgium (Jauniaux and Coignoul 1992) and Germany (Siebert and Frese 1993), the authors have been interested in the parasitological infestation of two species: a marine mammal, the harbour porpoise (Phocoena phocoena); and a sea bird, the common guillemot (Uria aalge). Parasites can be responsible for or involved in various diseases, and can be a cause of the stranding of solitary cetaceans (Geraci and Lounsbury 1993). Moreover, parasites can be biological indicators of the behaviour and the distribution of their hosts (Raga and Balbuena 1992). Their presence in large numbers could also 
TABLE 1: Helminths recorded in 248 common guillemots found dead on the Belgian coast

\begin{tabular}{lccc}
\hline Helminth species & $\begin{array}{c}\text { Birds infected } \\
\text { /examined }\end{array}$ & $\begin{array}{c}\text { Parasitised } \\
\text { birds (\%) }\end{array}$ & Location \\
\hline $\begin{array}{l}\text { Cestodes } \\
\text { Unidentified }\end{array}$ & $1 / 248$ & 0.4 & Intestine \\
$\begin{array}{l}\text { Nematodes } \\
\text { Contracaecum spiculigerum }\end{array}$ & $64 / 248$ & 25.8 & $\begin{array}{c}\text { Gizzard, } \\
\text { oesophagus }\end{array}$ \\
$\begin{array}{l}\text { Pentastomids } \\
\text { Reighardia sternae }\end{array}$ & $7 / 248$ & 2.8 & Air sacs \\
\hline
\end{tabular}

indicate changes in the marine ecosystem as a result of an imbalance between the parasites and their hosts (Borrens and Coignoul 1992).

\section{Materials and methods}

\section{Necropsies and sampling}

Eighteen harbour porpoises and 248 common guillemots were examined between February 1990 and July 1991. The porpoises had been found stranded or were bycaught, two along the Belgian coast and 16 along the German coast (eight of them being bycaught). The guillemots were found on the Belgian coast.

The necropsies were carried out according to standard protocols specific for sea birds (Pionneau 1987, Dorrenstein and Van Der Hage 1993) and marine mammals (Siebert and Frese 1993). The specimens for helminth evaluation were collected and rinsed in 0.9 per cent normal saline to remove mucus and debris, and then fixed in a large volume of fixative. The parasites were identified largely on the basis of the following tables and determination keys: Price (1932), Yamaguti (1958-1961), Self (1969), Arnold and Gaskin (1975), Berland (1982), Hong-Kean and Masashi (1982), Abril and others (1984) and Andersen (1987). Additional investigations including histology, bacteriology, virology and toxicology were also made.

\section{Identification of trematodes and cestodes}

Trematodes and cestodes were fixed in cold 4 per cent buffered formaldehyde, and extended in xylene between two slides. They were stained by immersion in boracic carmine (Langeron 1949), cleared in hydrochloric acid diluted in ethanol, and neutralised in 70 per cent ethanol saturated with sodium bicarbonate. The samples were dehydrated by immersion in graded alcohols and mounted in a synthetic medium. For the cestodes, the integument and underlying layers of muscle were stripped from the ventral surface of the strobilae to provide better details of the ducts (Berland 1982, Jones 1990). The best results were obtained by initial immersion in xylene before the stripping procedure.

In the porpoises, only a macroscopic examination of the stomach was made.

\section{Identification of nematodes}

The samples were fixed in cold 70 per cent alcohol and 2 per cent glycerine to prevent them from becoming dehydrated. The nematodes were examined as wetmounts in clearing agents, using glycerine for small worms and lactophenol for large worms.

\section{Determination of age and maturity}

The maturity of the guillemots was determined by an examination of the genital organs following the technique by Camphuysen and van Franeker (1992). Immature birds were considered to be
TABLE 2: Prevalence of infestation of 248 common guillemots with the helminth Contracaecum spiculigerum and the mean burden of worms in relation to the sex and age of the birds

\begin{tabular}{lccc}
\hline Categories & Number & Prevalence & Mean burden \\
\hline Males & 162 & $28 \cdot 4$ & $5 \cdot 2$ \\
Females & 86 & 20.9 & 4.8 \\
& & & \\
$<1$ year old & 23 & 17.4 & 4.3 \\
$>1$ year old & 225 & 26.7 & $5 \cdot 1$ \\
\hline
\end{tabular}

less than one year old and assigned to group 1, and mature birds were considered to be at least one year old and assigned to group 2. The age of the porpoises was determined by an examination of their teeth, using the methods described by Kremer (1987). The animals were separated into two age groups, those less than one year old (group 1) and older animals (group 2).

\section{Statistical analyses}

The relationships between the number of parasite species and the age or sex of the hosts were evaluated by the Kruskall-Wallis and Mann-Whitney tests.

The relationship between the ratio of parasitised and non-parasitised animals (the prevalence) was determined by the $\chi^{2}$ test for the guillemots and by the exact test for the porpoises, because of the small number of animals.

Parasite species occurring in at least 10 per cent of the animals were listed as common for that host, and only these species have been included in the statistical analyses.

Differences with $\mathrm{P}<0.05$ were accepted as statistically significant.

\section{Results}

Helminths belonging to three genera were collected from the 248 guillemots. Seventy-two guillemots were infected, the most common helminth being a nematode found in the gizzard of 64 birds.

A total of six helminth species were identified in the harbour porpoises, 16 ( 89 per cent) of which were infested by these parasites.

\section{Parasitic burdens of the guillemots}

Pentastomids of the species Reighardia sternae (Self 1969) occurred in the air sac. This species is generally not regarded as a primary cause of death in marine birds.

The nematode found in the gizzard and the oesophagus was identified as Contracaecum spiculigerum.

A chain of immature, unidentified proglottids was found in one bird.

Among the three species identified, only $C$ spiculigerum occurred in more than 10 per cent of the hosts (Table 1).

A $\chi^{2}$ analysis of the numbers of immature and adult birds infected with $C$ spiculigerum did not indicate a statistically significant difference in the number of parasites between the two age groups, the mean burden (mean number of worms/birds) being light in both groups (Table 2).

There was no significant difference between the number of male and female birds which were infected.

\section{Parasitic burdens of the porpoises}

One species of trematode, one cestode, and four nematodes were found in the porpoises. All the species except Diphyllobothrium stemmacephalum had a prevalence over 10 per cent (Table 3). 
TABLE 3: Helminths recorded in 18 harbour porpoises found dead on the Belgian and German coasts

\begin{tabular}{|c|c|c|c|}
\hline Helminth species & $\begin{array}{l}\text { Porpoises infected } \\
\text { /examined }\end{array}$ & $\begin{array}{c}\text { Parasitised } \\
\text { porpoises (\%) }\end{array}$ & Location \\
\hline \multicolumn{4}{|l|}{ Trematodes } \\
\hline Campula oblonga & $5 / 18$ & 28 & Liver \\
\hline \multicolumn{4}{|l|}{ Cestodes } \\
\hline Diphyllobothrium & & & \\
\hline stemmacephalum & $2 / 18$ & 11 & Intestine \\
\hline \multicolumn{4}{|l|}{ Nematodes } \\
\hline Pseudalius inflexus & $16 / 18$ & 89 & $\begin{array}{l}\text { Bronchus, } \\
\text { artery, heart }\end{array}$ \\
\hline Torynurus convolutus & $8 / 18$ & 44 & $\begin{array}{l}\text { Bronchus, } \\
\text { pharynx }\end{array}$ \\
\hline Stenurus minor & $5 / 18$ & 28 & Middle ear \\
\hline Anisakis simplex & $6 / 18$ & 33 & Stomach \\
\hline
\end{tabular}

Trematodes of the species Campula oblonga (Campulidae) occurred in the bile and pancreatic ducts (Table 3). This species was associated with chronic fibrotic cholangitis and hyperplasia of the bile ducts in all the animals infested. Coblonga has previously been reported in the liver and in the bile and pancreatic ducts of harbour porpoises along the coasts of Britain, Denmark and France (Clausen and Andersen 1985, Balbuena and others 1987, Baker and Martin 1992) and was associated with massive hyperplasia of the musosa. These histological observations are comparable with those observed during this survey.

One cestode of the species D stemmacephalum (Diphyllobothriidae) was found in the intestine of two porpoises (Table 3).

The nematode, Anisakis simplex (Ascaridoidea: Anisakidae) was recovered from the stomach (Table 3 ). This worm was associated with ulcers in three of the porpoises, and the prevalence of the ulceration was comparable with that observed by Baker and Martin (1992).

The last three species of nematodes identified, namely Pseudalius inflexus, Torynurus convolutus and Stenurus minor, belong to the Pseudaliidae family, which is composed almost exclusively of parasites of odontocetes (Table 3). $P$ inflexus was recovered from the bronchi and, in five cases, from the heart and pulmonary arteries. $T$ convolutus was found in the bronchi. In seven cases these worms were present in such large numbers that they occluded the bronchi almost completely or completely. They were associated with a chronic interstitial pneumonia. Clusters of macrophages and neutrophils were observed around the parasite larvae in the pulmonary tissue. The deaths of one porpoise from the Belgian coast and three from the German coast were attributed to this parasite. S minor was recovered from the middle ear, but no pathological changes were observed in association with these worms.

The prevalence of the parasites increased with the age of the porpoises except for $S$ minor (Table 4 ). In contrast, Clausen and Andersen (1985) observed an increase in the prevalence of $S$ minor with the age of porpoises in Danish waters.

The exact test showed a significant increase in the prevalence of parasites with age, but no difference between the sexes.

The Mann-Whitney test indicated that there was no significant difference between the number of parasite species in the male and female porpoises.

\section{Discussion}

The environment of the host is an important factor in relation to the presence of helminth species. When compared with guillemots from Newfoundland (Threlfall 1971), those collected along the Belgian coast were not heavily parasitised in terms of either the number of species or the parasitic burden. Twelve genera of helminths were found in the birds from Newfoundland compared with three genera in the birds collected on the Belgian coast. The low incidence of worms in the Belgian guillemots may be the result of environmental conditions in the area where the birds feed, these conditions possibly being unsuitable for the development of the larvae.
TABLE 4: Numbers of harbour porpoises infested with five common helminths in relation to the sex and age of the animals

\begin{tabular}{|c|c|c|c|c|c|c|}
\hline Categories & Number & $\mathrm{Pi}$ & Tc & $\mathrm{Sm}$ & As & Co \\
\hline Males & 9 & 6 & 4 & 2 & 2 & 1 \\
\hline Females & 9 & 9 & 4 & 3 & 4 & 4 \\
\hline$<1$ year & 8 & 6 & 3 & 3 & 2 & 1 \\
\hline$>1$ year & 10 & 9 & 5 & 1 & 4 & 4 \\
\hline
\end{tabular}

$\mathrm{Pi}$ Pseudalius inflexus, Tc Torynurus convolutus, Sm Stenurus minor, As Anisakis simplex, Co Campula oblonga

Oiling of birds could also be a factor in explaining the weak infestation of the guillemots from the Belgian coast, the oiled birds having lost their appetite and therefore having not picked up an infection (Borgsteede 1991). Another possibility is that crude oil can act as an antiparasitic substance; substances derived from crude oil, such as carbon tetrachloride and benzene derivatives, have been used as antiparasitic drugs.

The sex of the guillemots had virtually no influence on the structure of the helminth population. This was not surprising since there is no documented evidence that male and female guillemots display different behaviours in breeding or wintering. In contrast, in herring gulls (Larus argentatus), a species in which the male and female birds live in different habitats for most of the year, a difference in the helminth population of the sexes has been reported (Threlfall 1968).

The age of the host might be expected to be an important determinant of the composition of the burden of helminths. Very young birds have few parasites and are, therefore, not representative of the whole population (Bush 1989). However, the helminths present in the juvenile birds were very similar to those present in the older birds, probably because all the juvenile birds were more than three months old. These observations are comparable to those in communities of willets (Catoptrophorus semipalmatus), a species in which the immature birds live in similar conditions and feed like the adults from a very young age (Bush 1989).

To the best of the authors' knowledge, the life cycle of $C s p i$ culigerum, the only common parasite found in the guillemots from the Belgian coast, is still unknown. It is likely, however, that its intermediate hosts are planktonic crustaceans and fish (Lick 1990).

The helminth fauna of the porpoises from Belgian and German waters did not seem to differ substantially from that of porpoises from the rest of the European Atlantic, although no gastric trematodes were found. However, the lack of trematodes may have been due to the fact that the stomach of the porpoises was not examined thoroughly.

In the porpoises, the sex of the host seemed, as in the guillemots, to have no influence on the structure of the helminth fauna. The increase in the prevalence of parasites with age for certain species was different from observations in domestic animals (Kinze and others 1988), in which immature individuals are more sensitive to parasites. In adults, resistance develops to infestation by additional parasitic worms and recovery is prompted by the development of an immune response. However, when defence mechanisms are deficient, as a result of disease or debilitation, an increase in the number of parasites is observed.

The life cycle of $A$ simplex is better known than that of the other parasitic species found in the porpoises, because its larvae are present in edible teleosts and can cause gastric and other lesions in human beings eating raw fish. Some intermediate hosts of $C$ oblonga are still unknown. Apart from molluscs, other hosts most probably play a part in the cycle before the flukes infest cetaceans (Raga and Balbuena 1992). The life cycle of the Pseudalidae is completely unknown.

$T$ convolutus occurred in association with $P$ inflexus in the same animals. A similar case was reported in porpoises from French Atlantic waters (Balbuena and others 1987). The massive presence of two species in the respiratory system is a heavy burden on 
diving mammals such as the harbour porpoise, and parasitic bronchopneumonia was the cause of death of four ( 22 per cent) of the porpoises. The guillemots from the Belgian coast were, in general, weakly parasitised. This observation could indicate either that the birds were particularly healthy, or that the environmental conditions for the complex life cycle of the parasites were unfavourable, or that the diet of the birds lacked variety. In any case, it seems probable that parasitism was not responsible for the mortalities observed among common guillemots in the North Sea, the major cause of which is oil pollution (Camphuysen and van Franeker 1992).

The harbour porpoises all carried a large number of helminths of an appreciable range of species. These helminths, particularly those that infested the respiratory tract, had a significant impact on the health of the porpoises and were responsible for the death of four of them. The immature male found dead along the Belgian coast was massively infested with pulmonary, hepatic, intestinal and vascular parasites. However, the reasons for such a severe infestation in an immature animal were not clear.

Acknowledgements. - This work was partly subsidised by the EEC (NORSPA No 90-1/B/002-BA 3030/92/004295) and the Belgian Ministry of Public Health and Environment. The authors thank the rehabilitation centres of the Belgian coast (De Zwin, Oostende and Nieuwpoort) for collecting most of the guillemots, and the 'Institut Royal des Sciences Naturelles' for the identification of the birds. The first author expresses her gratitude to Professor Raga for his help in the identification of the parasites. Thanks are also due to Professor J.-M. Bouquegneau (Department of Oceanology of the University of Liège) who made this work possible.

\section{References}

ABRIL, E., ALMOR, P., RAGA, J. A. \& DUGUY, R. (1984) Bulletin de la Société Zoologique de France 111, 1

ANDERSEN, K. (1987) Journal of Natural History 21, 411

ARNOLD, P. W. \& GASKIN, D. E. (1975) Canadian Journal of Zoology 53, 713

BAKER, J. R. \& MARTIN, A. R. (1992) Veterinary Record 130, 554

BALBUENA, J. A., RAGA, J. A. \& DUGUY, R. (1987) Report of the 1987 meeting of the European Cetacean Society, Hirtshals, Denmark. p 56

BERLAND, B. (1982) Basic Techniques involved in helminth preservation. ICOPA V Workshop: Technology as applied to museum parasite collections. August 12 , 1982. Toronto, Canada. $\mathrm{p} 1$

BORGSTEEDE, F. H. M. (1991) Helminth parasites of wild birds. In Wild Bird Mortality in the Netherlands 1975-1989. Working group on wild bird mortality, Netherlands Society for the Protection of Birds. p37

BORRENS, M. \& COIGNOUL, F. (1992) Whales: Biology-Threats-Conservation. Ed J. J. Simoens. Brussels, Royal Academy of Overseas Sciences. p 167

BUSH, A. O. (1989) Helminth Communities: Determinants of Pattern. Eds G. Esch A. O. Bush, J. A. Aho. Chapman and Hall. p197

CAMPHUYSEN, C. J. (1989) Beached bird surveys in the Netherlands 1915/1988 Technisch Rapport Vogelbescherming 1. Zeist, Vogelbescherming Nederland. p 214

CAMPHUYSEN, C. J. \& VAN FRANEKER, J. A. (1992) Technisch Rappor Vogelbescherming 10. Zeist, Vogelbescherming Nederland. p 51

CLAUSEN, B. \& ANDERSEN, R. (1985) Health status of harbour porpoises (Phocoena phocoena) from Danish waters. International Council for the Exploitation of the Sea, CM. 1985/N10. 12 pp

DORRENSTEIN, G. \& VAN DER HAGE, M. (1993) Proceedings of the 1993 European Conference of Avian Medicine and Surgery, Utrecht, The Netherlands. Dutch Association of Avian Veterinarians. p 120

GERACI, J. R. \& LOUNSBURY, V. J. (1993) Marine Mammals Ashore. A field guide for strandings. Ed Texas A \& M University. Texas A \& M Sea grant Publication. p 77

HONG-KEAN, O. \& MASASHI, O. (1982) Japanese Journal of Veterinary Research 30, 112

JAUNIAUX, T. \& COIGNOUL, F. (1992) Rapport Final de Convention 1991-1992, Faculté de Médecine Vétérinaire, Service d'Anatomie Pathologique, Université de Liège, Belgique

JONES, A. (1990) Systema Parasitologica 15, 211

KINZE, C. C., EVANS, P. G. H., SMEEK, C., ADDINK, M. J. \& BAKKER, J. (1988) Report of the International Workshop on the Harbour Porpoise at the Sea Mammals Unit, Cambridge. European Cetacean Society

KREMER, H. (1987) Untersuchungen zur altersbestimmung an schweinswalen (Phocoena phocoena) (Lin. 1758). Diplomarbeit aus dem Institut fü Haustierkunde der Christian-Albrechts-Universität Kiel

LANGERON, M. (1949) Précis de Microscopie. 7th edn. Eds Masson and Cie. France, Brodard et Taupin. p 556

LICK, R. R. (1990) First record of fish intermediate hosts of Contracaecum species larvae, probably C osculatum Rudolphi, 1802, and Anisakine nematode maturing in pinnipeds in the German Wadden Sea. International Council for the Exploitation of the Sea, CM 1990/N17. $22 \mathrm{pp}$

PIONNEAU, F. (1987) Point Vétérinaire 19, 469

PRICE, E. W. (1932) The trematode parasites of marine mammals. Proceedings of the US National museum. Vol 81, Art. 13

RAGA, J. A. \& BALBUENA, J. A. (1992) Whales: Biology-Threats-Conservation. Ed J. J. Simoens. Brussels, Royal Academy of Overseas Sciences. p 187

SELF, J. T. (1969) Experimental Parasitology 24, 63

SIEBERT, U. \& FRESE, K. (1993) Untersuchungen über bestand, Gesundheibanstand und Wanderingen der kleinwalpopulationen (Cetacea) in deuschen Gewessern. Eds H. Benke, H, Bohlken. Endbericht zum FE-Vorhaben das BMU. Nv. 10805017/11, December 1993, Institut für Hanstierkunde Universität Kiel. p 121

THRELFALL, W. (1968) Canadian Journal of Zoology 46, 1119

THRELFALL, W. (1971) Canadian Journal of Zoology 49, 461

YAMAGUTI, S. (1958-1961) Systema Helminthum. Vols 1-3. New York \& London, Interscience Publishers.

\section{Abstracts \\ Bone growth and $1,25(\mathrm{OH})_{2}$-vitamin $\mathrm{D}_{3}$ in chickens}

THE incidence of defects of endochondral ossification was different in two distinct strains of commercial broilers which were both fed the same nutritionally adequate diet. Between one and 21 days of age the incidence of tibial dyschondroplasia in one strain varied from 10 to 20 per cent, whereas in the other strain it varied from 10 to 70 per cent and 40 per cent of the bone samples collected at 14 days of age had lesions of calcium deficiency rickets. The serum concentration of 1,25-dihydroxycholecalciferol was significantly lower in the second than in the first strain, except in the day-old chicks. These results suggest that tibial dyschondroplasia in some strains of broiler is related to an inherent predisposition to rickets and to lower serum concentrations of 1,25-dihydroxycholecalciferol.

PARKINSON, G., THORP, B. H., AZUOLAS, J. \& VAIANO, S. (1996) Research in Veterinary Science 60, 173

\section{Interaction of nutrition and genotype on haemonchosis in sheep}

PROTEIN supplementation has been shown to improve the resistance of some breeds of sheep to haemonchosis. Blackface sheep are more resistant to the disease than other breeds and this paper describes experiments to test whether protein supplementation would be beneficial to this resistant breed. Blackface lambs were fed either a basal diet or the same diet supplemented with soyabean meal to give an additional $80 \mathrm{~g}$ crude protein $/ \mathrm{kg}$ dry matter; some of them were then given an initial dose of Haemonchus contortus followed by a trickle infection for 10 weeks. The weight gains of the supplemented lambs were greater and their carcases were leaner, irrespective of their infection status. The infected animals on the basal diet were more anaemic and hypoalbuminaemic than those on the supplemented diet, although there were no significant differences between them in worm burdens or faecal egg counts.

WALlACE, D. S., BAIRDEN, K., DUNCAN, J. L., FISHWICK, G., GILL, M., HOLMES, P. H., McKELLAR, Q. A., MURRAY, M., PARKINS, J. J. \& STEAR, M. (1996) Research in Veterinary Science 60, 138 